\title{
Mineração
}

\section{Concentration of bauxite fines via gravity concentration}

\author{
(Concentração de finos de bauxita por \\ concentração densitária)
}

\section{Resumo}

A CBA (Companhia Brasileira de Alumínio) tem uma usina de beneficiamento em Itamarati de Minas, MG. Essa usina trata dois tipos de bauxita diferentes, um originado da laterização de gnaisses e outro de anfibolitos. Ambos os minérios têm o mesmo comportamento nas frações granulométricas grosseiras, mas tornam-se diferentes abaixo de $0,355 \mathrm{~mm}$ (42 \# Tyler). Nesses tamanhos menores, os minérios gnáissicos são ricos em quartzo e os anfibolíticos são minerais portadores de ferro e titânio.

As operações unitárias de preparação são a desagregação da alimentação em desagregadores de tambor ("scrubbers"), a deslamagem em ciclones e o peneiramento do minério desagregado em peneiras de alta freqüência em 0,355 $\mathrm{mm}$ (42\# Tyler) - o produto retido em $0,355 \mathrm{~mm}$ é um concentrado final. O produto passante em 0,355 mm é deslamado em dois estágios de ciclones e vai para a separação final em espirais Reichert, sendo tal operação completada por separação magnética do produto leve das espirais.

O trabalho de desenvolvimento de pesquisa, incluindo mineralogia, desenvolvimento de processo, ensaios em bancada e em escala-piloto, é descrito nesse trabalho e comparado com os resultados operacionais do circuito industrial.

\section{Arthur Pinto Chaves}

Prof. Dr., Universidade de São Paulo.

E-mail: arthurchaves@terra.com.br

\section{Mauricio Bergerman}

Universidade de São Paulo.

E-mail: mauricio.bergerman@poli.usp.br

\section{Claret Antonio Vidal Abreu}

Gerente de Produção, Companhia Brasileira de Alumínio, Departamento de Itamarati de Minas Email: claret.abreu@vmetaiscba.com.br

\section{Nilson Bigogno}

Companhia Brasileira de Alumínio, Departamento de Itamarati de Minas

Email:

nilson.bigogno@vmetaiscba.com.br
Palavras-chave: Preparação de bauxita, concentração gravimétrica, espirais Reichert.

\section{Abstract}

Companhia Brasileira de Aluminio (CBA) has a preparation plant at Itamarati de Minas, MG. This plant washes two different kinds of bauxite ore, one originating from the laterization of gnaisses and another from amphybolites. Both ores have the same behavior in the coarser size fractions but behave differently under $0.355 \mathrm{~mm}$ (42\# Tyler). In these small sizes, gneissic ores are rich in quartz and amphybolitic ores are rich in iron and titanium bearing ores.

The unit operations are: scrubbing of the feed in drum scrubbers, desliming in cyclones, and screening of the scrubbed bauxite in high frequency screens $(0.355 \mathrm{~mm})$ - the $+0.355 \mathrm{~mm}$ product is a final concentrate. The $-0.355 \mathrm{~mm}$ fraction is desliming in two stage cyclones and goes to a fines gravity concentration circuit of Reichert spirals complemented by magnetic separation of the light product from the spirals.

The research work, including mineralogy, process development, batch tests and pilot plant tests, is described and compared to the actual results in the industrial circuit.

Keywords: Bauxite preparation, gravity concentration, Reichert spirals. 


\section{Introduction}

As far as the authors are aware, the bauxite processing practice only exists in Brazil. In the other producing countries, the richest ores are directly fed to the refinery plant. Depending on the silica / available alumina ratio of the ores, poorer ores can be fed to especially designed refineries.

In Brazil, bauxite processing is routine, and a few examples can be listed:

- Mineração Rio do Norte, at Oriximiná (PA), dresses bauxite via scrubbing, desliming in a complex cyclone circuit, and dewatering in vacuum filters (Reis, 2004).

- Mineração Santa Lucrécia, at Monte Dourado (PA), had a circuit to prepare ceramic grade bauxite via heavy media separation in Dynawhirlpool separators (Sampaio \& Neves, 2005).

- Companhia Brasileira de Alumínio (CBA), at Poços de Caldas (MG), uses scrubbing, optical sorting and desliming in cyclones.

- CBA, at Itamarati de Minas, MG, scrubs, screens, deslimes, and uses Reichert spirals and magnetic separation to recover bauxite from fines (Bergerman, 2003; Bergerman and Chaves, 2004; Kurusu, 2005).

- Mineração Rio Pomba, at Mercês (MG), uses jigs to separate the coarse silica.

- VALE is starting-up a new project at Paragominas (PA), using semiautogenous grinding and desliming in cyclones.

This paper describes CBA's development of the fine bauxite circuit at Itamarati de Minas.

CBA has a strong commitment to sustainable development in mining and metallurgy. This considers the best recovery in minerals preparation as well as the minimal generation of tailings to be disposed in the environment. The effort to recover the bauxite values contained in the fines is mainly due to this commitment.

\section{Itamarati de Minas Department}

CBA belongs to the Votorantim Group and operates a mine and preparation plant at Itamarati de Minas, MG

The plant started operations in 1992. It works with two types of ore. The first one is the product of laterization of gneissic rocks; its main contaminants are silica and clay-minerals. The second one comes from the weathering of amphybolitic rocks; its main contaminants are $\mathrm{Fe}_{2} \mathrm{O}_{3}, \mathrm{TiO}_{2}$ and clay minerals.

In 1992, the flowsheet consisted of:

- Primary crushing to reduce ore under $125 \mathrm{~mm}\left(5^{\prime \prime}\right)$.

- Primary scrubbing.

- Primary screening in $25 \mathrm{~mm}(1 ")$ and $6.35 \mathrm{~mm}(1 / 4 ")$ sieves.

- Secondary crushing of the material retained in the $25 \mathrm{~mm}(1 ")$ sieve.

- Secondary scrubbing of the crushing product and of the minus $25 \mathrm{~mm}(-1)$ $+6.35 \mathrm{~mm}(1 / 4 ")$.

- Secondary screening in $6.35 \mathrm{~mm}(1 / 4 ")$ (the oversize of this secondary screening is a final product).

- $-1 / 4$ " fines are screened in $1.2 \mathrm{~mm}$ (14\# Tyler) (the oversize of this screening is another final product and its undersize is a tailing).

Mass recovery for a concentrate with $42 \%$ available alumina was $43.5 \%$, metallurgical recovery was $61 \%$, and monthly production was 30,000 tons.

In 1996, the sieves for primary screening were changed from 1 to $2 "$ and from $1 / 4$ " to $1.2 \mathrm{~mm}$. Secondary screening started to use the same sieve. Tertiary screening was eliminated.

The undersize of these operations $(-1.2 \mathrm{~mm})$ started to be deslimed in $26 "$ cyclones. The cyclone underflow started to be sent to high frequency screens with $0.3 \mathrm{~mm}$ (48\# Tyler) sieves.
Mass recovery increased to $48.5 \%$ and metallurgical recovery, to $67 \%$. Monthly production increased to 34,000 tons.

In the beginning of 1999, 26" cyclones were exchanged for $15 "$ cyclones of different design. Underflow rate (or $0.3 \mathrm{~mm}$ screens feed) increased, demanding three additional screens. By this time the $0.3 \mathrm{~mm}$ sieves were exchanged for $0.35 \mathrm{~mm}$ (42\# Tyler) sieves. Mass recovery increased to $55.5 \%$ and metallurgical recovery, to $75 \%$. Monthly production increased to 45,000 tons.

Until 2000, both types of ore amphybolitic and gneissic - were dressed together. This is correct, as their behaviour is similar down to the $0.35 \mathrm{~mm}$ size. The differences start under this size - the contaminants for both ores are segregated at this fraction: the amphybolitic ore is diluted by iron and titanium ores whereas the gnaissic ore is diluted by quartz (Oba, 2000).

If an effort was to be made to increase the bauxite recovery in the finer sizes, the two ores had to be processed individually. Tests indicated that an increase in bauxite recovery was feasible for the amphybolitic ore - iron and titanium minerals can be separated by magnetic separation. But, as this operation is an expensive one, gravity separation in shaking tables and concentrating spirals was tested. It showed to be useful and led to a cheaper configuration where only the bauxite concentrate (a minor portion of the feed flow) was sent to the high intensity magnetic separator.

The gneissic ore could be separated by the same process, but, as its quartz content is very high, the increase in available alumina grade is not significant, and the results are not interesting.

A pilot plant was erected at the industrial plant. Both ores (one by one and together) and different circuit configurations were tested: with and without previous desliming, with two and three spirals stages, with internal 
recycling to the spirals, different splitting of the products etc. Feed flow rate to the spirals was varied to measure their actual capacity.

As results were obtained, they were jointly analysed and discussed by the EPUSP and CBA teams. Testing evolution and changes in circuit configuration were then defined.

Figure 1 shows the pilot plant which was operated for 3 months. It had one 6 " cyclone, two or three Reichert spirals (depending on the circuit configuration), a high intensity wet magnetic separator and auxiliary equipment such as pumps.

This experimental campaign has provided the necessary information for the industrial circuit project.

It has also provided an important insight about the intrinsic variability of the bauxite ores. Mining in the Zona da Mata region is done at the top of the high mountains where laterization occurred. Deposits are small and the quality of the ore varies from one another. It also varies inside the ore body, in horizontal as well as in vertical directions.

The pilot plant operation allowed us to detect such a variability, to measure it, and to be able to design a robust preparation plant, i.e., a set of equipment with extra capacity reserve, able to absorb such a variation. This means that all the equipment must have extra capacity to be able to deal with extreme variations in feed characteristics.

\section{Amphybolitic ore preparation}

Based on these conclusions, the industrial circuit was complemented: since 2004, the undersize of the high frequency screens has been sent to a battery of 6" cyclones. They are designed to classify $-\mathrm{d}_{95}$ of $0.06 \mathrm{~mm}$ (250\#) - extracting the fines with high reactive silica content which make the slurry viscous, worsening gravity separation performance. The cyclone underflow is processed in two stages of concentrating spirals. Each stage extracts a heavy minerals product (a tailing). The light and the middlings products of the first stage are reprocessed in the second stage. The middlings product of this stage returns to the first stage and the light one is sent to the high intensity wet magnetic separator.

In this way, a small part of the feed flow is sent to the more expensive magnetic separation. The middlings magnetics are recycled in the same equipment. It is important to highlight that the middlings are liberated particles that were not separated at the first pass through the equipment. Problems with the liberation of the middlings were not observed. Non magnetics - the final product - are dewatered and added to the coarser concentrate. The magnetics are joined to the heavy product from the spirals, dewatered in a spiral classifier and stored.

Mass recovery of the full plant reaches $60 \%$ when working with the amphybolitic ore and proper feed rates. Metallurgical recovery goes up to $90 \%$ in such a situation. In ordinary operation, alternating the two ore types, mass recovery reaches $59 \%$.

Figure 2 shows the industrial plant. Figure 3 shows the pile where the heavy product of this circuit is stacked. Figure 4 shows the present flowsheet.

\section{Use of tailings}

The described work applies only to the amphybolitic ore. When the plant operates with it, the tailings produced are the 15" cyclone overflow, the -

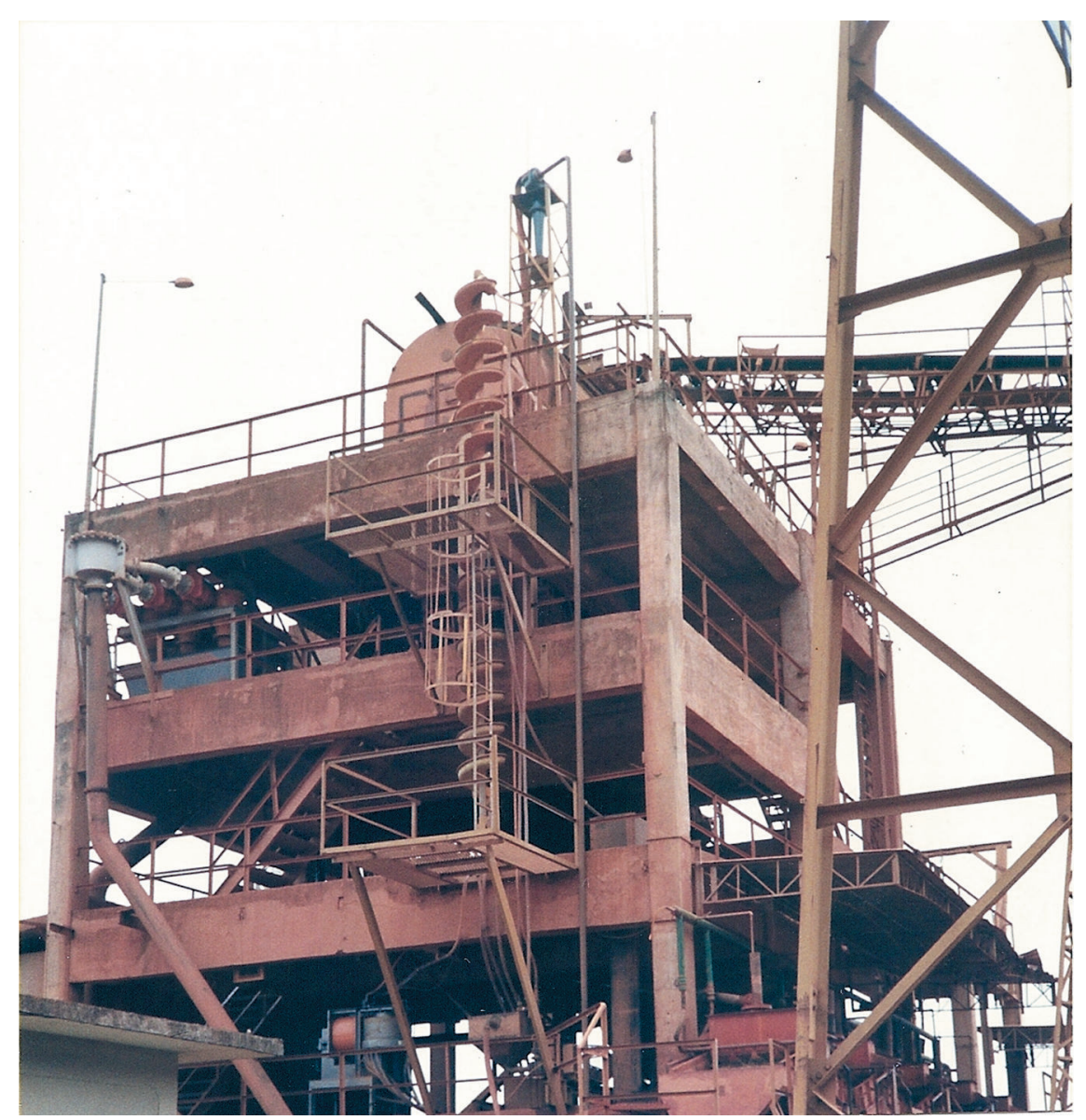

Figure 1 - Pilot plant. 
$0.35+0.21 \mathrm{~mm}$ fraction, the $6 "$ overflow, the heavy product and the magnetic product.

When operating with the gneissic ore, the tailings are the 15 " overflow, the $0.35+0.21 \mathrm{~mm}$ fraction, and the $-0.21 \mathrm{~mm}$ fraction.

Characterization studies on the heavy and on the magnetic products have shown high concentrations of iron and titanium (about $62 \% \mathrm{Fe}_{2} \mathrm{O}_{3}$ and $28 \% \mathrm{TiO}_{2}$ ) plus gibbsite and magnesite.

Cantagalo is a neighboring region where Portland cement is produced. The high grade limestone that is used demands clay and hematite additions for proper clinker composition.

Our basic idea when developing this circuit was to return the heavy minerals concentrate to the final pit bottom and to bury it before mining reclamation. But then tests were carried out at the Portland cement plant, substituting both clay and hematite for this product.

Positive results were found: gibbsite and goethite behave the same way as clay and hematite. Unexpected benefits came from the hitherto unknown behaviour of the titanium ore. It acted as a fluxant for clinker, lowering clinkerization temperature.

This allows the furnace to operate at a lower temperature, saving fuel oil, increasing the refractories life, decreasing the number of maintenance stops and thus increasing the number of productive hours. This leads to significant economy in the cement plant.

The use of this tailing avoids the disposal of 25,000 tons per year into the tailings dam.

The other tailings at the moment are the overflows of the 15 " and 6" cyclones. These are very fine materials, about $94 \%$ $-0.074 \mathrm{~mm}$ (200\# Tyler). They are composed of gibbsite, kaolinite, hematite, pseudorutile and grenalite. There is then potential for its use as raw material for ceramics production.

Initial tests consisted in separating the $-5 \mu \mathrm{m}$ fraction and in preparing 9 pressed briquettes. They were burned to 900 , 950 e $1000^{\circ} \mathrm{C}$, yielding a very nice red colour and presenting good mechanical strength. Contraction, water absorption and porosity gave satisfactory results.

The next step was the extrusion testing of the full overflows (not only the $5 \mathrm{~mm}$ fraction). The pure product is not good, but blended with plastic clays led to miniatures such as those shown in Figure 5.

\section{Conclusion}

The use of the gravity concentration process, including classification in cyclones, and magnetic separation proved to be feasible for the bauxite from CBA's operations. Plant production and available alumina increased as a result of their

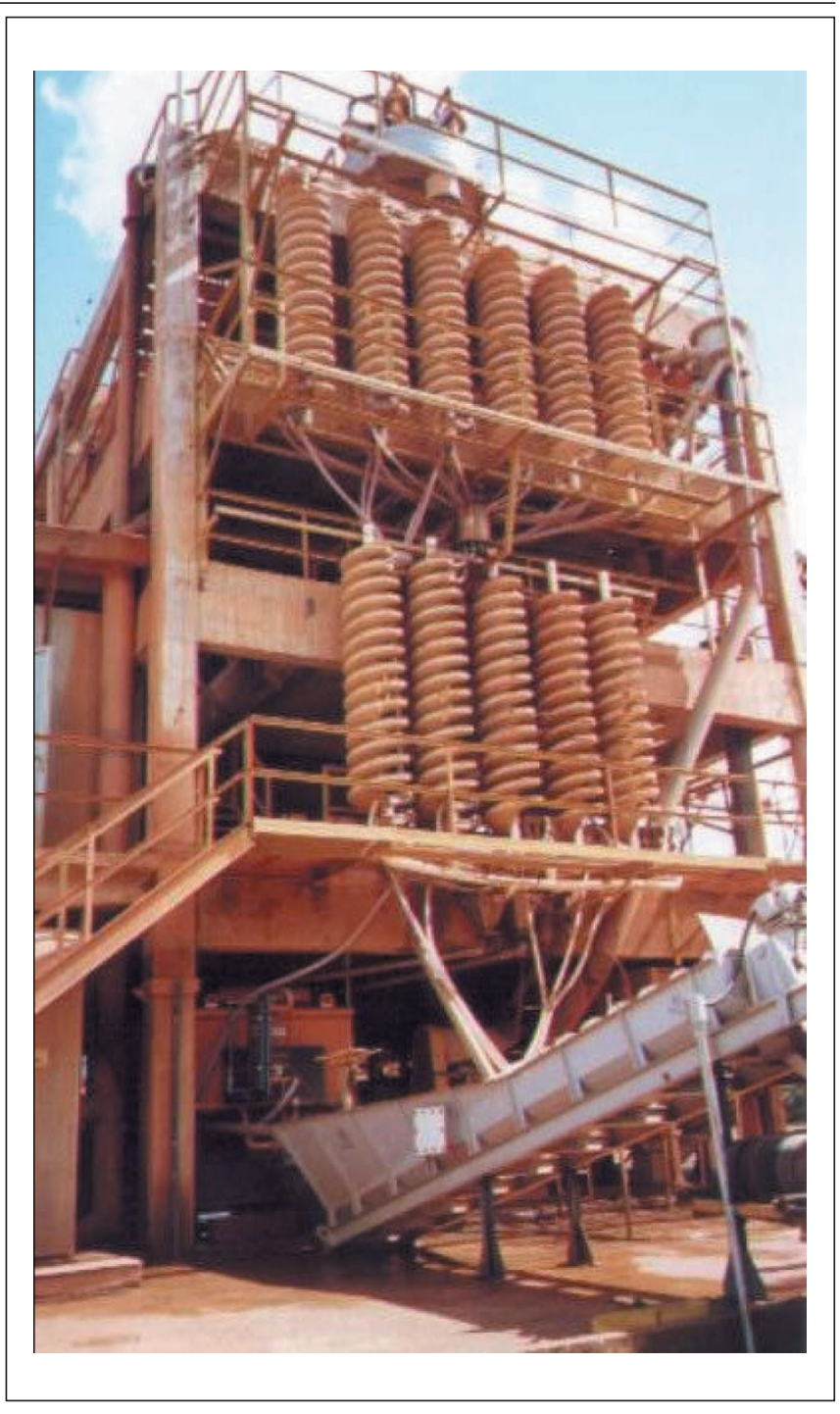

Figure 2 - Industrial plant.

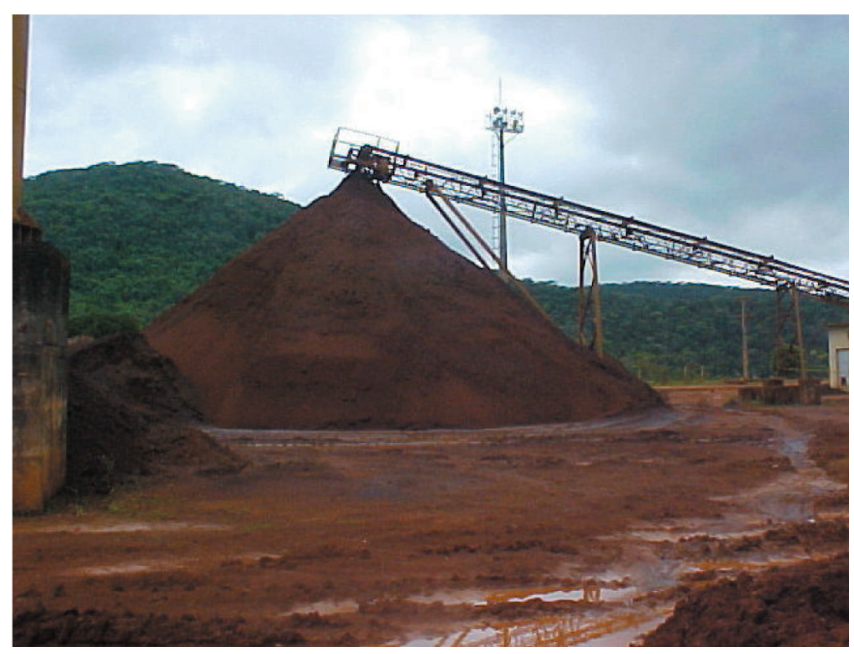

Figure 3 - Heavy minerals concentrate pile. 


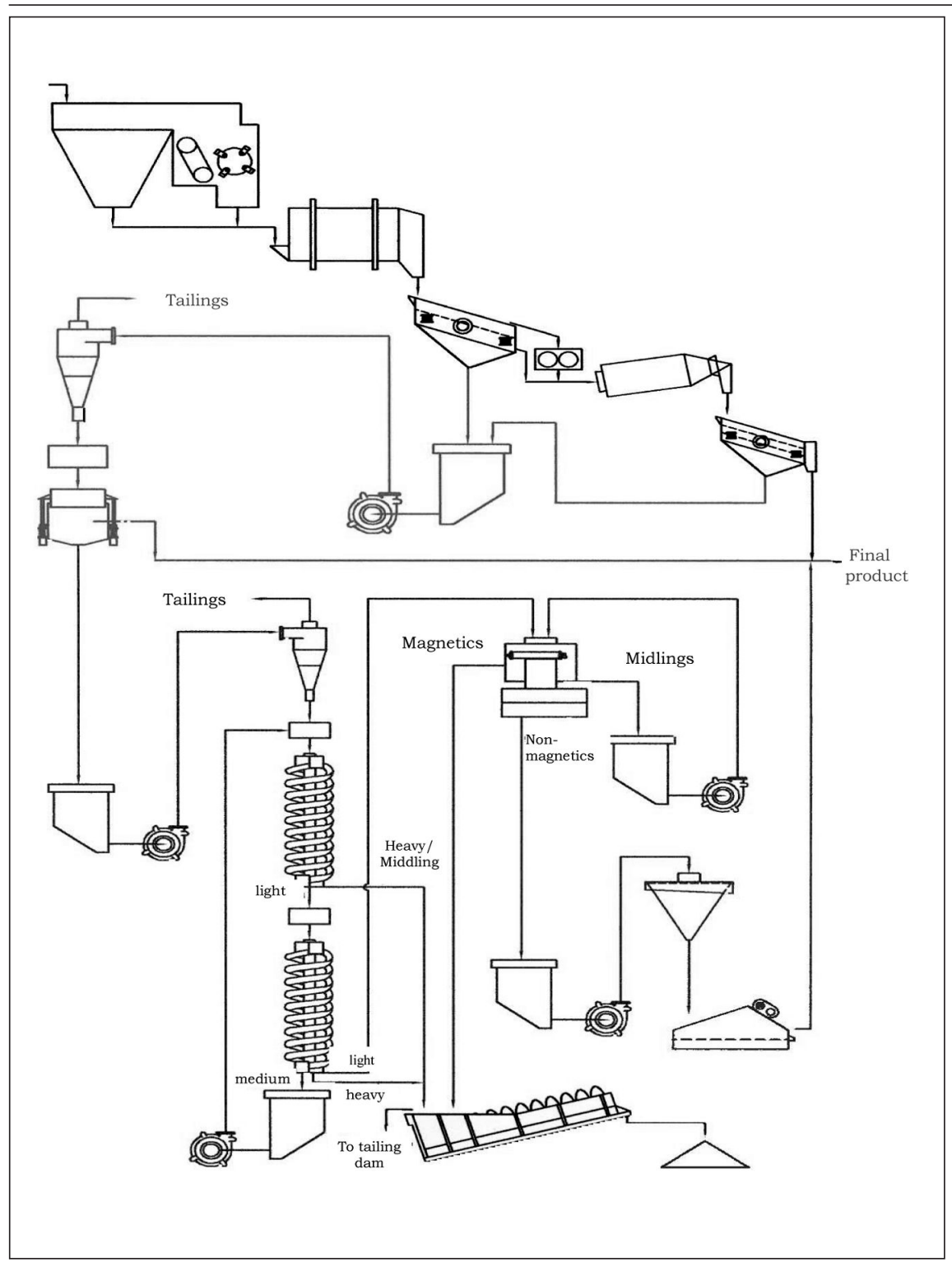

Figure 4 - Present flowsheet.

application. This represents a novel development and for the first time, the application of such processes in bauxite processing.

As an associated result, tailings were transformed into by-products. This is especially welcome as our initial purpose was to decrease the intensity of the environmental impact caused by tailings disposal.

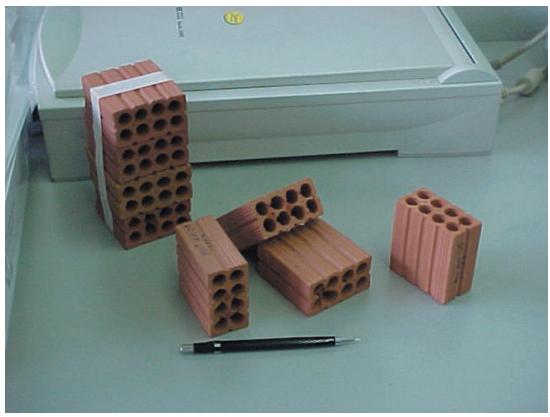

Figure 5 - Extruded brick miniatures.

\section{References}

BERGERMAN, M.G. Produção mais limpa no tratamento de minérios: caso da Companhia Brasileira de Alumínio, Mina de Itamarati de Minas, MG. São Paulo: Escola Politécnica da Universidade de São Paulo, 2003. 37p. (Monografia Trabalho de Formatura).

BERGERMAN, M.G., CHAVES, A.P. Experiência de produção mais limpa na CBA. Brasil Mineral, São Paulo, n. 231, p. 16-24, Aug. 2004.

KURUSU, R.S. Flotação de finos de bauxita. São Paulo: Escola Politécnica da Universidade de São Paulo, 2005. 43 p. (Monografia -Trabalho de Formatura).

OBA, C.A.I. Caracterização dos rejeitos de bauxita de Itamarati e Descoberto. São Paulo: APChaves Assessoria Técnica, 2000. (Relatório interno).

REIS, R.L.G. MRN completa 25 anos com expansão concluída. Brasil Mineral, São Paulo, n. 227, p. 14-19, May 2004.

SAMPAIO, J.A.,NEVES, C.H.B. Bauxita MSL Minerais S.A. In: Usinas de beneficiamento de minérios no Brasil. Rio de Janeiro: Cetem/MCT, 2005. p. 307314.

Artigo recebido em 28/06/2008 e aprovado em 21/05/2009.

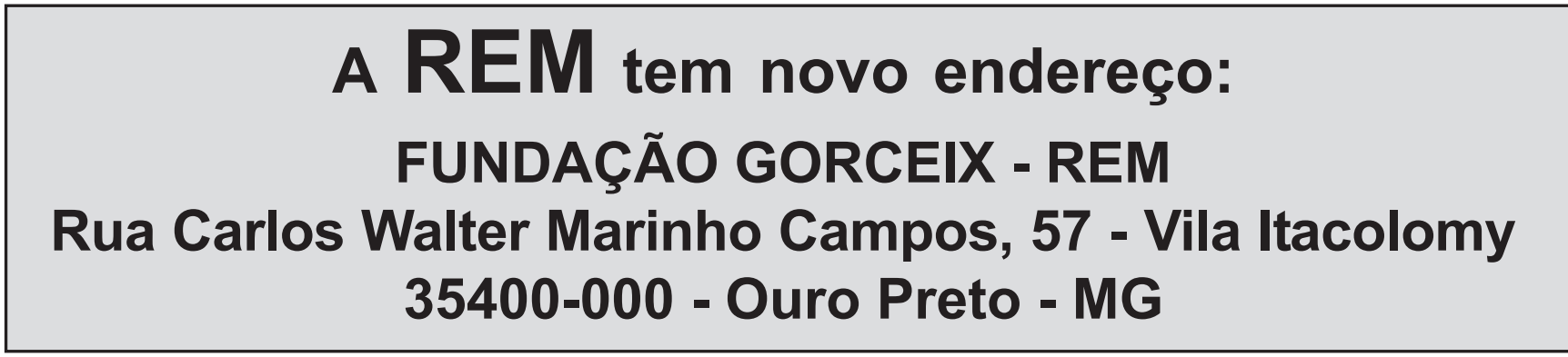

